\title{
CLIMATE CHANGES AND EFFECTS ON RIVER FLOW IN THE ROMANIAN CARPATHIANS
}

\author{
L. ZAHARIA ${ }^{1}$, R. PERJU ${ }^{2}$, G. IOANA-TOROIMAC ${ }^{2}$
}

\begin{abstract}
Effects of climate change on river flow in the Romanian Carpathians. The paper highlights some relevant changes detected in Romania, namely in the Carpathian area, and related impacts on streamflow. It focuses on Valea Cerbului River catchment, a small mountainous watershed (extended over $26 \mathrm{~km}^{2}$, in the eastern extremity of the Southern Carpathians), where observed and projected changes of the river flow were presented based on frequency and trend analysis of recorded discharges and on hydrological modeling. As observed changes (between 1950-2010), general upward significant trends in the variability of the average discharge were detected, for both annual and monthly discharges (mostly in October, January and July). The projected changes were estimated by the WaSiM-Eth hydrological model for 2035-2065 period, compared to the reference period 1961-1991 (using climatic data on the A1B scenario obtained within the project ENSEMBLE). The results showed the increase of high flows in the cold season (December - April) and a significant decrease in discharges during the warm season (June - November, mainly in August - September).
\end{abstract}

Keywords: climate change, linear trends, streamflow, WaSiM-ETh model, Carpathian Mountains, Valea Cerbului River.

\section{INTRODUCTION}

Changes in climate parameters represent one of the most important global issues, with multiple and various impacts on all environmental components. As the climatic and hydrological systems are closely related, any change of climatic parameters have direct or indirect hydrological effects (Prăvălie et. Al., 2016).

This paper focuses on Romania, namely on the Romanian Carpathians, aiming to synthetically highlight changes observed in the main climatic parameters and their impacts on the river flow. Several previous studies have dealt with hydroclimatic changes and trends throughout Romania. The most numerous were on climatic parameters. Among the most recent studies we mentions: Busuioc et al. (2010), Bîrsan and Dumitrescu (2014), Dumitrescu et al. (2014), Bojariu et al. (2015), Croitoru et al. (2016a, b), etc. Some papers were strictly focused on climate trends and changes in the Romanian Carpathians area, such as those published by: Micu (2009), Croitoru et al. (2011), Bîrsan et al. (2014), Cheval et al. (2014), Micu et al. (2015a, b, c); Croitoru et al. (2016c) etc.

\footnotetext{
1 University of București, Faculty of Geography, Bd. Nicolae Bălcescu 1, 010041, București, Romania, e-mail: zaharialili@hotmail.com; gabriela.toroimac@geo.unibuc.ro

${ }^{2}$ National Institute of Hydrology and Water Management, ruth.perju@hidro.ro
} 
Concerning the impacts of climate changes on the hydrological parameters and regime in Romania, there are several previous studies at both national and regional scale (at watershed level), such as: Stănescu et al. (1999), Şerban (2006), Zaharia and Gălie (2007), Perju and Zaharia (2014), Perju et al. (2014), Bîrsan et al. (2012, 2014), Corbuș et al. (2011, 2017), Mic et al. (2017) etc.

This paper synthesizes, in the first part, the most relevant results from previous researches on climate changes in Romania and the Romanian Carpathians. In the second part, we focus the analysis on Valea Cerbului River catchment (located in the Carpathian area), where observed and projected changes in streamflow were detected, based on frequency and trend analysis of measured discharges and on simulations using hydrological modeling.

\section{OBSERVED CLIMATE CHANGES IN ROMANIA AND THE CARPATHIANS}

The climate of Romania is greatly influenced by the presence, in its central part, of the Carpathian mountain archwise chain (with the maximum altitude of 2544 $\mathrm{m}$ a.s.1.), occupying about $30 \%$ of the country's territory (Fig. 1.a). The mean multiannual temperature in Romania varies with latitude (from $8^{\circ} \mathrm{C}$ in the North to $11^{\circ} \mathrm{C}$ in the South) and altitude (from $11-12^{\circ} \mathrm{C}$ in the plains, to less than $0^{\circ} \mathrm{C}$ at the highest altitudes in the Carpathians). The mean multiannual amounts of precipitation increase from less than $300 \mathrm{~mm}$ (in the south-east, in Dobrogea region) to more than $1200 \mathrm{~mm}$ on the Carpathians' heights (NAM, 2008).
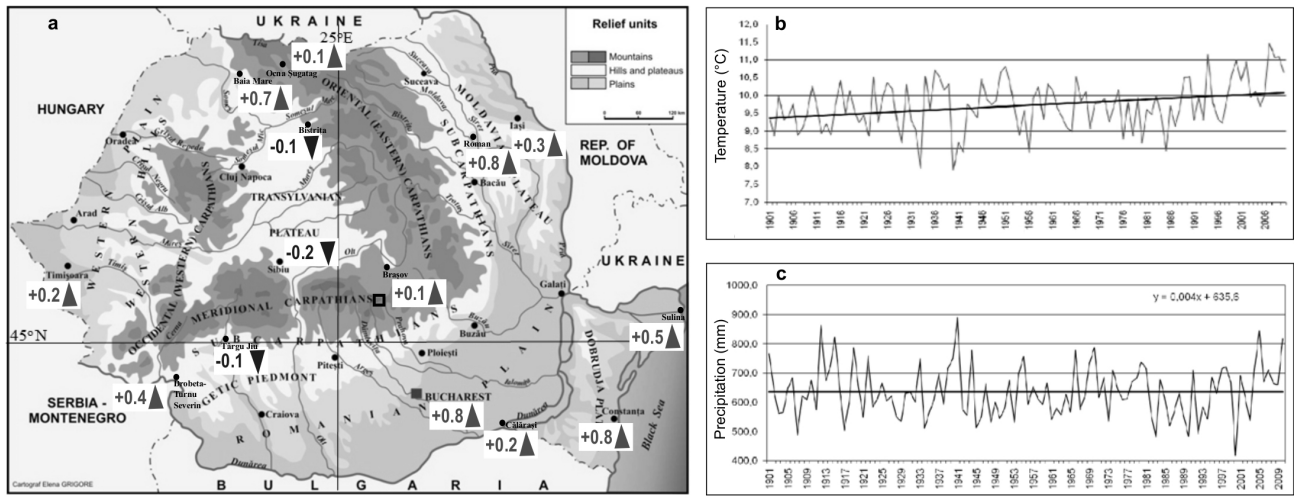

Fig. 1. a: Changes in the mean multiannual air temperature $\left({ }^{\circ} \mathrm{C}\right)$ in Romania (19012000); b: Mean annual air temperature variation in Romania and the linear trend (19012010); $c$ : Annual precipitation variation in Romania and the linear trend (1901-2010) (sources: fig. a - modified from MESD, 2008; fig. $b$ and $c$ - modified from Sandu, 2013). The small square on fig. a marks the location of the Valea Cerbului River catchment

Previous studies showed an evident warming trend in Romania, consistent with the global trend of warm-related indicators. During the last century (more precisely after 1900), the mean multiannual air temperature increased in Romania 
by up to $0.8^{\circ} \mathrm{C}$, with regional differences (MESD, 2008; NAM, 2014): higher warming in the southern and eastern part of the country (e.g. București, Constanța, Roman areas) and lower warming in Carpathian areas, as well as slight decrease in air temperature in some regions (Fig. 1.a and b). Concerning the precipitation, throughout the Romanian territory, during the period 1901-2010, the changes in their variation are not statistically significant (Fig. 1.b); however, different regional trends were identified.

Studies on recent climatic changes (1961-2013) in Romania (Dumitrescu et al., 2014; Bojariu et al., 2015), based on observational data recorded at 150 weather stations (w.s.), showed statistically significant upward seasonal trends in air temperature, especially in spring and summer and partially in winter. The trends identified in autumn were not statistically significant. The warming tendencies were confirmed by the trends in the annual thermal extremes, in the number of summer days, as well as by other warm-related indices. Regarding the precipitation, the annual amount is rather stable; seasonally, positive trends were identified for several stations in autumn (especially in the central and western parts of Romania) and negative trends for a few stations in the other seasons. Upward trends were identified at several weather stations for daily maximum rainfall (mainly in summer and autumn), which increases the flood risk in these seasons (Dumitrescu et al., 2014; Bojariu et al., 2015). During the period 1961-2013, the trend analysis of the data recorded at 104 weather stations showed significant negative trends for the number of days with snow cover ( $40 \%$ of the stations). The same trend was detected in the average thickness of the snow pack (20\% of the analyzed stations) (Bojariu et al., 2015).

Recent studies on the Carpathians area (e.g. Micu, 2009; Cheval et al., 2014; Micu et al., 2015 a, b) show some climate changes after 1961, mainly a general warming. This is proven by positive trends in warm-related indices and negative trends in cold-related indices. Significant positive trends of air temperature were detected in all seasons, except for autumn which seems to be thermally stable. On the other hand, autumn is the only season for which the precipitation had significant upward trends; for the other seasons precipitation did not show significant trends. It is worth noting that in Romania in general and in the Carpathians in particular, general decreasing trends were found in: mean snow depths, number of days with snow cover, number of days with snowfall and continuous snow cover duration, changes related mainly to the recent warming and to the slight decrease in winter amounts of precipitation (Micu et al., 2015a, b).

\section{CHANGES IN RIVER FLOW REGIME AND HYDROLOGICAL PARAMETERS IN THE CARPATHIANS. CASE STUDY: VALEA CERBULUI RIVER WATERSHED}

\subsection{Study area, data and methods}

Valea Cerbului is a small watershed (of only $26 \mathrm{~km}^{2}$ ) located in the Bucegi Mountains, in the eastern extremity of the Southern Carpathians (Fig. 1.a). It has a high relief energy $(1640 \mathrm{~m})$ and a mean altitude of about $1540 \mathrm{~m}$. Valea Cerbului 
River has a total length of $9.8 \mathrm{~km}$, with a mean slope of $132 \mathrm{~m} / \mathrm{km}$. The upper part of the catchment, developed over calcareous conglomerates, has steep slopes with gradients between $45^{\circ}$ and $80^{\circ}$ (Perju and Zaharia, 2014).

The climate is imposed by the high altitudes: the mean multiannual air temperature varies between approx. $6^{\circ} \mathrm{C}$ in the lower part of the catchment, to $-2.5^{\circ} \mathrm{C}$ at $\mathrm{Omu}$ Peak w.s., located at $2505 \mathrm{~m}$ a.s.l., where the frost lasts, in average, 260 days/year and the snow layer has a mean duration of 140-220 days/year, with a monthly average thickness of up to $70-80 \mathrm{~cm}$ in March-April. The mean annual precipitation amount in Valea Cerbului catchment reaches 900-1030 mm (NAM, 2008).

The studied watershed is monitored at Bușteni gauging station (g.s.), controlling approx. 96\% of the total area of the catchment. Over the period 1961-2010, the mean multiannual discharge of Valea Cerbului River at Bușteni g.s. was $0.49 \mathrm{~m}^{3} / \mathrm{s}\left(19.1 \mathrm{1} / \mathrm{s} / \mathrm{km}^{2}\right)$. The flow regime is characterised by high water volumes in summer ( $38 \%$ from the mean multiannual volume), with the maximum percentages in June and July (13\% and respectively $15 \%$ of the mean multiannual water volume), due to heavy rains specific for this season. An important water volume is also specific in spring (30\%), when the runoff is generated by rainfall cumulated with snowmelt. Low flow is specific for both winter and autumn (13\% and respectively 19\%) (Perju, 2012).

The study is mostly based on hydrological data, namely on annual maximum and mean daily discharge recorded between 1961 and 2010 at Bușteni g.s. and obtained through the "Romanian Waters" National Administration (RWNA).

In order to identify changes in Valea Cerbului River flow, frequency and trend analysis of measured discharges was carried out. The significance of linear trends was determined using the Mann-Kendall test and Sen's slope method, developed on an Excel template (Salmi et al., 2002).

The projected changes in hydroclimatic parameters were estimated using the fully distributed hydrological model WaSiM-ETh (Water Balance Simulation Model), which requires daily data on several climatic parameters (air temperature, precipitation, sunshine duration, wind velocity, air relative humidity) as input. The model was calibrated (with the PEST software) and validated using hystorical daily discharges measured/determined at Bușteni g.s. The efficiency of the model was assessed with two objective functions, namely the Nash-Sutcliffe Efficiency Coefficient (NSE $=0.80$ for calibration and $\mathrm{NSE}=0.60$ for validation) and the Pearson Correlation Coefficient $(\mathrm{r}=0.90$ for calibration and $\mathrm{r}=0.86$ for validation). In order to simulate the possible changes in flow regime, induced by the changes in climatic parameters (air temperature, precipitation and snow cover), we used climatic scenario data as input in the hydrological model. The selected IPCC scenario is a rather balanced one, namely the A1B scenario (the data were obtained within the project ENSEMBLE, at Max Plank Institute, using the ECHAM5 climatic model), for the horizon 2035-2065. The reference period is 1961-1991. For both, the reference period and scenario data, bias corrections (delta change method, as described by Hawkins et al., 2013) were applied to the two most important climatic input parameters: air temperature and precipitation. 


\subsection{Observed changes in Valea Cerbului River flow}

A previous study (Perju, 2012) showed for the period 1950-2010 upward statistically significant trends in the variability of mean annual and monthly discharges. The most important trends (with the level of significance $\alpha$ of 0.001 to 0.01) were identified for October, January and July. A significant upward trend was detected for the spring season.

Based on the trend analysis of the annual maximum discharge, we found that, between 1961-2010, the magnitude of the annual floods had an upward trend, statistically significant (with $\alpha=0.1$ level of significance) (Fig. 2.a). Positive trends were identified in autumn and winter (with $\alpha=0.1$ level of significance) and negative trends in spring (but statistically not significant). The annual number of floods (defined as daily discharges three times greater than the mean multiannual annual discharge, consecutive such values being considered as a single flood) recorded between 1961-2010, showed a slow ascending, but statistically not significant trend (Fig. 2.b). A higher frequency of large floods (considering the monthly number of cases with flows greater than the average of annual maximum discharges) was detected after 1990 (Fig. 2.c).

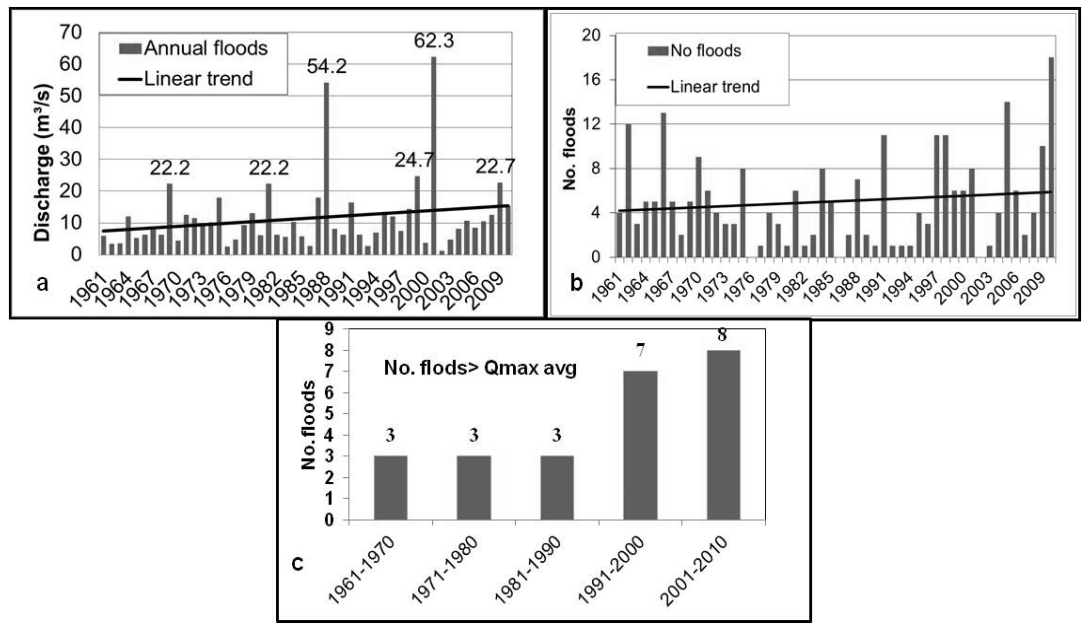

Fig. 2. Variability of the maximum flow and floods at Bușteni g.s. on Valea Cerbului River (1961-2010); a: Maximum annual discharges (annual floods) and their linear trend; b: Annual number of floods (as defined in text) and the linear trend; $c$ : Decadal frequency of floods (monthly number of cases with flows greater than the average of annual maximum discharges - Qmax avg)

\subsection{Projected changes in the Valea Cerbului River flow regime}

Considering the A1B scenario, the results of the simulations made with WaSiM-ETh showed an increase of air temperatures and a decrease of precipitation amounts and snow stock, for the period 2035-2065. The general shift of the solid 
precipitation to liquid form in late winter and early spring, significantly reduces cumulative snow depths, leading to substantially lower summer river flows. Likewise, the reduced stock of snow in spring and early summer decreases the probability that a warm spring-summer rain event can combine with snowmelt to generate higher peak flows.

The impact of these changes in climatic parameters upon Valea Cerbului flow regime is reflected by: increasing discharges in the cold season (December to April), with up to $30 \%$ and their diminution in June - November, with more than 25-30\% in August and September (Fig. 3.a and b); increasing number of days with low flow (mainly in August and September); diminution of annual number of days with high flow, but with seasonal and monthly differences (increasing in spring, mainly in April; decreasing in summer, mainly in June).

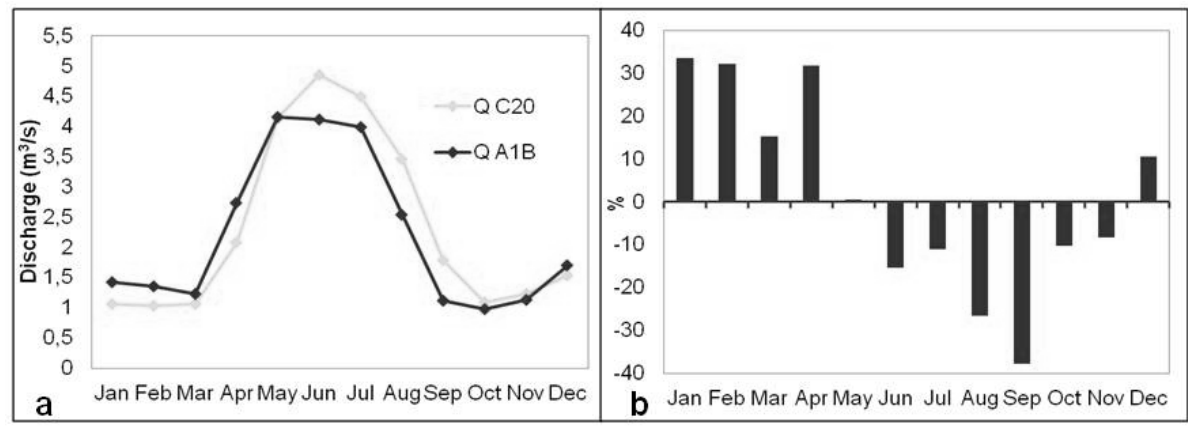

Fig. 3. Expected impact of climate change on the flow regime of the Valea Cerbului River: a: monthly average discharge; $b$ : relative difference between the reference period - Q C20 (1961-1991) and the scenario - Q A1B (2035-2065)

\section{CONCLUSIONS}

This paper showed synthetically the most important climatic changes in Romania, with focus on the Carpathians, and the related impacts on the river flow in a watershed (Valea Cerbului River) located in the eastern extremity of the Southern Carpathians. The most important climate changes with hidrological impacts detected after 1961 are: general warming at annual and seasonal scale (excepting autumn); increasing precipitation amounts in autumn and daily maximum rainfall (mainly in summer and autumn); downward trends in snow-related indices (mean snow depth, number of days with snow cover and with snowfall, continuous snow cover duration). The changes in the climatic parameters could explain some modifications and trends in river flow regime, detected in Valea Cerbului River catchment, such as: a general upward trend in spring and autumn; an upward trend in the magnitude of floods; a higher frequency of large floods in the last decades (after 1990). As possible future changes, the results of the simulations at the watershed scale mainly showed the increase of high flows in the cold season (December - April) and a significant decrease in discharges during the warm season (June - November, mainly in August - September). 
In order to diminish the negative effect induced by the climate changes on water resources and on socio-economical fields in Romania, a Guide on adaptation to climate changes was elaborated in 2008 by the Ministry of Environment and Sustainable Development and the National Strategy on Climate Changes was adopted and approved by the Government in 2016.

\section{REFERENCES}

1. Bîrsan, M.V., Dumitrescu, A. (2014), Snow variability in Romania in connection to large-scale atmospheric circulation. International Journal of Climatology 34(1), 134-144.

2. Bîrsan, M.V., Dumitrescu, A., Micu, D.M., Cheval, S. (2014), Changes in annual temperature extremes in the Carpathians since AD 1961. Natural Hazards 74, 1899-1910.

3. Bojariu, R., Bîrsan, M.V., Cică, R., Velea, L., Burcea, S., Dumitrescu, A., Dascălu, S.I., Gothard, M., Dobrinescu, A., Cărbunaru, F., Marin, L. (2015), Schimbările climatice - de la bazele fizice la riscuri și adaptare, Printech, București.

4. Busuioc, A., Caian, M., Cheval, S., Bojariu, R., Boroneanț, C., Baciu, M., Dumitrescu, A. (2010), Variability and Climate Change in Romania. Pro Universitaria, București (in Romanian).

5. Cheval, S., Bîrsan, M.V., Dumitrescu, A. (2014), Climate variability in the Carpathian Mountains region over 1961-2010. Global and Planetary Change 118, 85-96.

6. Corbuş, C., Mic, R., Mătreață, M. (2011), Assessment of climate change impact on peak flow regime in the Mureș river basin. XXVth Conference of Danubian Countries, 16 - 17 June, Budapest.

7. Corbuş, C., Mic R.P., Mătreață, M., Chendeș, V., Preda, A. (2017), Potential climate change impact on mean flow in Romania. Danube Conference 2017, Electronic book with full papers, Golden Sand, Bulgaria, 548-557.

8. Croitoru, A.E., Dragotă, C.S., Moldovan, F., Holobâcă, I., Toma, F.M. (2011), Considérations sur l'évolution des températures de l'air dans les Carpates roumaines. Actes du XXIV ème Colloque International de l'Association Internationale de Climatologie, 147-152.

9. Croitoru, A.E., Piticar, A., Burada, D.C. (2016a), Changes in precipitation extremes in Romania. Quaternary International 415, 325-335.

10. Croitoru, A.E., Piticar, A., Ciupertea, A.F., Roșca, C.F. (2016b), Changes in heat waves indices in Romania over the period 1961-2015. Global and Planetary Change 146, 109-121.

11. Croitoru, A.E., Drignei, D., Burada, D.C., Dragotă, C.S., Imecs, Z. (2016c), Altitudinal changes of summer air temperature trends in the Romanian Carpathians based on serially correlated models. Quaternary International 415, 336-343.

12. Dumitrescu, A., Bojariu, R., Bîrsan, M.V., Marin, L., Manea, A. (2014), Recent climatic changes in Romania from observational data (1961-2013). Theoretical and Applied Climatology.

13. Hawkins, E., Osborne, T.M., Ho, C.K, Challinor, A.J. (2013), Calibration and bias correction of climate projections for crop modelling: An idealised case study over Europe, Agr. Forest Meteorol., 170, 19-31. 
14. MESD (Ministry of Environment and Sustainable Development) (2008), Ghid privind adaptarea la schimbările climatic, București.

15. Mic, R.P., Corbuș, C., Mătreață, M., Preda, A., (2017), Efectul schimbărilor climatice potențiale asupra debitelor maxime în bazine hidrografice din România. Annual Conference of NIHWM, Book of Abstracts, București, 27-28.

16. Micu, D. (2009), Snow pack in the Romanian Carpathians under changing climatic conditions. Meteorology and Atmospheric Physics 105(1-2),1-16.

17. Micu, D.M., Dumitrescu, A., Cheval, S., Bîrsan, M.V. (2015a), Observed variability and trends from instrumental records. Climate of the Romanian Carpathians, Springer Atmospheric Sciences, Springer, Cham, 149-185.

18. Micu, D.M., Dumitrescu, A., Cheval, S., Bîrsan, M.V. (2015b), Changing climate extremes in the last five decades (1961-2010). Climate of the Romanian Carpathians, Springer Atmospheric Sciences, Springer, Cham, 187-198.

19. Micu, D.M., Dumitrescu, A., Cheval, S., Bîrsan, M.V. (2015c), Projections of future changes in climate of the Romanian Carpathians. Climate of the Romanian Carpathians, Springer Atmospheric Sciences, Springer, Cham, 199-205.

20. NAM (National Administration of Meteorology) (2008), Clima României, Edit. Academiei Române, București p.

21. NAM (National Administration of Meteorology) (2014), Adaptation measures in Romanian agriculture, SEE Project-OrientGate: A structured network for integration of climate knowledge into policy and territorial planning. National Administration of Meteorology, București.

22. Perju, R. (2012), Flow control factors and runoff characteristics in the Valea Cerbului River Basin. Air and Water - Components of the Environment, 503-510.

23. Perju, R., Zaharia, L. (2014), Changes in the frequency and magnitude of floods in the Bucegi Mountains (Romanian Carpathians). Proceedings of "Water resources and wetlands" Conference, 321-328.

24. Perju, E.R., Zaharia, L., Balin, D., Lane, S. (2014), Changements climatiques dans les Carpates Roumaines et impacts hydrologiques. Étude de cas: les Monts de Bucegi. Actes du XXVIIe Colloque de l'Association Internationale de Climatologie, 73-79.

25. Prăvălie, R., Zaharia, L., Bandoc, G., Petrișor, A., Ionuș, A., Mitof, I. (2016), Hydroclimatic dynamics in southwestern Romania drylands over the past 50 years. Earth System Science 125(6), 1255-1271.

26. Salmi, T., Määttä, A., Anttila, P., Ruoho-Airola, T., Amnell, T. (2002), Detecting trends of annual values of atmospheric pollutants by the Mann-Kendall test and Sen's slope estimates - the Excel template application MAKESENS. Publications on Air Quality 31, Helsinki.

27. Sandu, I. (2013), Schimbări climatice în Romania și efectele asupra resurselor de apă $\hat{\imath}$ agricultură, Conference of the National Administration of Meterology, 27 mai, București.

28. Stănescu, V.A., Corbuş, C., Simota, M. (1999), Modelarea impactului schimbărilor climatice asupra resurselor de apă, HGA, București.

29. Şerban, A.C. (2006), Impactul schimbărilor climatice asupra resurselor şi sistemelor de gospodărire a apelor, Tipored, București.

30. Zaharia, L., Gălie, A. (2007), Changements climatiques et impacts sur le régime hydrologiques des rivières en Roumanie. Actes du XX eme Colloque International de Climatologie, 591-596. 